\title{
Bioproduction of cytochalasin D by endophytic fungus Xylaria sp. DAP KRI-5
}

\author{
Ahmad Fathoni, Andria Agusta* \\ Research Center for Biology, Indonesian Institute of Sciences, Bogor, Indonesia.
}

\section{ARTICLE INFO \\ Received on: 09/12/2017 \\ Accepted on: 04/08/2018 \\ Available online: 30/03/2019}

\section{Key words:}

Isolation, characterization,

bioproduction, cytochalasin

$\mathrm{D}$, endophytic fungus.

\begin{abstract}
Recently, endophytic fungi have attracted attention due to their ability to produce a variety of bioactive metabolites. In the course of our study on endophytic fungi associated with Albertisia papuana Becc, it has been found the endophytic fungus Xylaria sp. DAP KRI-5 produce cytochalasin D. Isolation of cytochalasin D was conducted by using an open column chromatography method. The chemical structure of cytochalasin D was deduced from 1 dimension, 2 dimension nuclear magnetic resonance, and ultra-performance liquid chromatography quadrupole time of flight mass spectrometry analyses and also compared with the published data. The bioproduction capacity of cytochalasin D by the fungus Xylaria sp. DAP KRI-5 was $0.05763 \mathrm{~g} / 1$.
\end{abstract}

\section{INTRODUCTION}

Endophytic fungi are microorganisms that live inside plant tissues without causing negative effects to its host plant (Petrini, 1991). Endophytic fungi can produce diverse bioactive secondary metabolites (Zhang et al., 2006). Various bioactive compounds produced by endophytic fungi have many kinds of biological activity such as anticancer, antibiotic, antifungal, and antidyslipidemic. Some of those bioactive substances are taxol, an anticancer compound produced by the fungus Taxomyces andreanae (Stierle et al., 1993), (+)-1,1'-bislunatin and (+)-2,2'-epicytoskirin A, antibacterial, and anticancer compounds produced by the fungus Diaporthe sp. GNBP-10 (Agusta et al., 2006; Praptiwi et al., 2013), micafungin, an antifungal compound from Coleophoma empetri (Frattarelli et al., 2004), rosuvastatin from Penicillium citrinum and $P$. brevicompactum, which is used for treating dyslipidemias (Scott et al., 2004).

\section{${ }^{*}$ Corresponding Author}

Andria Agusta, Research Center for Biology, Indonesian Institute of Sciences, Cibinong, Bogor, Indonesia.E-mail: andr002@lipi.go.id
In previous work, screening of antibacterial activity of 15 endophytic fungi from leaves and young stems of a medicinal plant, Albertisia papuana Becc.: Menispermaceae, resulted in one selected fungus, Xylaria sp. DAP-KRI-5. This fungus produced some bioactive metabolites with strong antibacterial activity against Staphylococcus aureus. The lead compounds as the bioactive metabolites from this fungus have been characterized as phloroglucinol (Fathoni et al., 2013), and cytochalasin D (unpublished data). Isolation, characterization, and bioproduction of cytochalasin D from Xylaria DAP KRI-5 have not yet been studied.

Cytochalasin D was first isolated by Aldridge et al. (1967) and was also known as zigosporin A (Hayakawa et al., 1968). The bioproduction capacity of cytochalasin D has been reported from Xylaria sp. SCSIO 156 in liquid medium (2\% mannitol, $2 \%$ malt extract, $1 \%$ glucose, $1 \%$ sodium glutamate, $0.05 \% \mathrm{KH}_{2} \mathrm{PO}_{4}, 0.03 \% \mathrm{MgSO}_{4} \cdot 7 \mathrm{H}_{2} \mathrm{O}, 0.1 \%$ corn meal, $0.3 \%$ yeast extract, and 3\% sea salt in distilled water and $\mathrm{pH} 6.5$ ), Xylaria sp. BT05 in a medium of $1,000 \mathrm{~g} / 1$ of rice in seawater and Xylaria arbuscula in a medium of $1,333 \mathrm{~g} / \mathrm{l}$ of wheat in distilled water (Amarala et al., 2014; Chen et al., 2011; De Felício et al., 2015).

To the best of our knowledge, there are no reports on the bioproduction capacity and antibacterial activity of cytochalasin $\mathrm{D}$ that have been produced by Xylaria $s p$. DAP KRI-5 in a 
medium of potato dextrose broth. In this study, we evaluated the bioproductive capacity and antibacterial activity of cytochalasin D from Xylaria sp. DAP KRI-5 associated with the A. papuana Becc plant.

\section{MATERIALS AND METHODS}

\section{Fungal growth}

Endophytic fungus DAP-KRI-5 was isolated from $A$. papuana Becc. plant collected from the Bogor Botanical Garden, West Java. This fungus was identified as Xylaria sp. in a previous study (Fathoni et al., 2013) and were preserved at $-80^{\circ} \mathrm{C}$ in the culture collection of InaCC, Indonesia. This fungus was cultured in $2.71(12 \times 200 \mathrm{ml}$ in a $500-\mathrm{ml}$ culture flask and $1 \times 300 \mathrm{ml}$ in a 1,000-ml culture flask) of potato dextrose broth (PDB) at $25^{\circ} \mathrm{C}$ for 14 days in the dark. The fungal culture was harvested and extracted three times with ethyl acetate (EtOAc). The extracts were filtered and concentrated using a rotary evaporator.

\section{Extraction and isolation of cytochalasin D}

Isolation of cytochalasin D from an EtOAc extract of Xylaria sp. DAP KRI-5 was conducted by using column chromatography. The EtOAc extract was applied on Sephadex ${ }^{\mathrm{TM}}$ LH-20 (GE Healthcare) (200 g) and eluted with methanol. The dominant fraction was then fractionated by using a $\mathrm{SiO}_{2}$ gel 60 (Merck) (70-230 mesh ASTM, $100 \times$ weigh of samples), using n-hexane-EtOAc eluent in the ranges of $3: 1$ to $1: 3$, followed by $\mathrm{CHCl}_{3}-\mathrm{MeOH}$ in the ranges of 5:1 to $1: 7$. The biggest weight fraction F2.3 (113.0 mg) was further applied on a $\mathrm{SiO}_{2}$ gel 60 (Merck) (70-230 mesh ASTM, $100 \times$ weigh of samples eluted with n-hexane-EtOAc in ranges of $6: 1$ to $0.5: 6$ ) resulting a pure compound (1), which was then analyzed for its chemical structure by high-resolution mass spectroscopy (HRMS), ${ }^{1} \mathrm{H}-$, and ${ }^{13} \mathrm{C}$-nuclear magnetic resonance $\left({ }^{13} \mathrm{C}-\mathrm{NMR}\right)$, and antibacterial activity by microdilution methods.

\section{Chemical structure analysis}

\section{High-resolution mass spectroscopy}

Analysis of HRMS of $\mathbf{1}$ was performed using an ultraperformance liquid chromatography quadrupole time of flight mass spectrometer (UPLC-qTOF-MS/MS) System (Waters). The experimental conditions were column Acquity UPLC BEH (C18 $1.7 \mu \mathrm{m}, 2.1 \times 50 \mathrm{~mm}$ ); flow rate of $0.3 \mathrm{ml} / \mathrm{minute}$; Temperature $40^{\circ} \mathrm{C}$, mobile phase using a linear gradient of $5 \% \mathrm{ACN}$ in milliQ water going to $100 \% \mathrm{ACN}$ for 7 minutes. Both solvents were buffered with $1 \%$ formic acid, at an injection volume of $5 \mu$. The analyte infusion experiments were performed using an in-built syringe pump. A UPLC-qTOF-MS with an electrospray ionization (ESI) interface was used for MS/MS analysis. ESI parameters were the capillary voltage of $3 \mathrm{kV}$ for the positive mode; a source temperature of $110^{\circ} \mathrm{C}$; a desolvation temperature of $300^{\circ} \mathrm{C}$; a cone gas flow of $16 \mathrm{l} / \mathrm{hour}$ and a desolvation gas flow of $550 \mathrm{l} / \mathrm{h}$.

\section{${ }^{1} \mathrm{H}$ - and ${ }^{13} \mathrm{C}-\mathrm{NMR}$}

${ }^{1} \mathrm{H}$ - and ${ }^{13} \mathrm{C}-\mathrm{NMR}$ spectra were recorded in $\mathrm{CDCl}_{3}$ on a JEOL JNM-Lambda 500 spectrometer at 500 and $125 \mathrm{MHz}$, respectively. Chemical shift was expressed in $\delta$ values relative to an internal standard of trimethyl silyl.

\section{Antibacterial assays}

The tested bacteria were cultured in Mueller Hinton Broth (Difco) in an incubator at $37^{\circ} \mathrm{C}$ overnight. The compound was tested against a panel of two Gram-positive bacteria (Staphylococcus aureus-InaCC B4 and Bacillus subtilis-InaCC B1) and two Gram-negative bacteria (Escherichia coli-InaCC B5 and Pseudomonas aeruginosa-InaCC B3). The inoculum was prepared as described previously. The cytochalasin D and the commercial antibiotic were dissolved in $2.5 \%$ sterile filtered dimethyl sulfoxide. Bacteria were cultured in the same manner and the compound was serially diluted two-fold across the wells of 96-well plates (Nunc ${ }^{\mathrm{TM}}$ ) with concentrations ranging from 0.25 to $32 \mu \mathrm{g} / \mathrm{ml}$ (final concentration), and plated in triplicate $(n=3)$. The resultant mid-log phase cultures were diluted to a concentration of $5.10^{5} \mathrm{CFU} / \mathrm{ml}$ and included a sterile control (containing broth culture) and a growth control (containing broth culture and bacteria, without antimicrobial substance). MIC is defined as the lowest concentration showing no visible growth (clear) and was determined visually after the addition of $20 \mu \mathrm{l}$ of Iodonitrotetrazolium chloride (INT, Sigma-Aldrich) water solution $(4 \mathrm{mg} / \mathrm{ml})$. The color in the wells changes to purple after the addition of INT if there is a bacterial growth. The commercial antibiotics, vancomycin hydrochloride (Sigma-Aldrich), streptomycin sulfate (Sigma-Aldrich), and chloramphenicol (Sigma) were used as positive controls. The results were expressed in $\mu \mathrm{g} / \mathrm{ml}$.

\section{RESULTS}

Endophytic fungus, Xylaria sp. DAP-KRI-5, isolated from A. papuana Becc plant that was collected from Bogor Botanical Garden, West Java, was cultured in 2.71 of PDB at $25^{\circ} \mathrm{C}$ for 14 days in the dark. The culture of this fungus was harvested and extracted with EtOAc. The extraction process yielded $2.7887 \mathrm{~g}$ of EtOAc extract.

Extract of Xylaria sp. DAP KRI-5 was fractionated by using column chromatography. First, the extract of EtOAc (600 $\mathrm{mg}$ ) was fractionated by Sephadex ${ }^{\mathrm{TM}} \mathrm{LH}-20$ (GE Healthcare) (200 g, eluent metanol) and resulted in F1-F5 (weights were $34.2,300.4,4.0,244.4$, and $1.1 \mathrm{mg}$, respectively). Then, the dominant fraction F2 $(208.7 \mathrm{mg})$ was applied on a $\mathrm{SiO}_{2}$ gel 60 (Merck) (70-230 mesh ASTM, $100 \times$ weigh of samples, eluent n-hexane-EtOAc in the ranges of $3: 1$ to $1: 3, \mathrm{CHCl}_{3}-\mathrm{MeOH}$ in the range of $5: 1$ to $1: 7$ ). This resulted in F2.1-F2.9 (respective weights were $12.9,19.8,113.5,11.3,18.2,4.9,17.7,5.8$, and $3.6 \mathrm{mg})$. Next, the biggest weight fraction, F2.3 (113.0 mg) was further fractionated by using $\mathrm{SiO}_{2}$ gel 60 (Merck) (70-230 mesh ASTM, $100 \times$ weight of samples in n-hexane-EtOAc in the range of $6: 1$ to $0.5: 6$ ) and resulted in F2.3.1-F2.3.10 (respective weights were $0.7,0.2,0.6,1.6,0.6,1.0,1.9,3.5,17.3$, and 1.3 $\mathrm{mg}$ ). One fraction, F2.3.9, was pure compound 1 which was analyzed by HRMS, 1D- and 2D-NMR, and antibacterial activity was tested using microdilution methods.

Data of HRMS of pure compound 1 were obtained using UPLC-qTOF-MS/MS: m/z value $\mathrm{M}^{+}$of 507.2615 (calc. 507.2611, $\Delta+0.4 \mathrm{mmu}$ ) with the molecular formula $\mathrm{C}_{30} \mathrm{H}_{37} \mathrm{NO}_{6}$.

The ${ }^{1} \mathrm{H}-\mathrm{NMR}$ and distortionless enhancement by polarization transfer (DEPT) data of $\mathbf{1}$ showed the presence of benzyl with aromatic proton at $\delta_{\mathrm{H}} 7.12(2 \mathrm{H}, \mathrm{d})$; 
$7.31(2 \mathrm{H}, \mathrm{t}) ; 7.25(1 \mathrm{H}, \mathrm{t})$ and two diastereotopic methylene protons of $\mathrm{H}-10$ were shifted upfield at $\delta_{\mathrm{H}} 2.67(1 \mathrm{H}$, dd) and $2.82(1 \mathrm{H}, \mathrm{dd})$, one exocyclic olefinic proton of $\mathrm{H}-12$ was shifted downfield at $5.09(1 \mathrm{H}, \mathrm{s})$ and $5.29(1 \mathrm{H}, \mathrm{s})$, two trans-disubtituted of $\mathrm{H}-13 / \mathrm{H}-14$ and $\mathrm{H}-19 / \mathrm{H}-20\left[\delta_{\mathrm{H}} 5.14(1 \mathrm{H}, \mathrm{dd}), 5.69(1 \mathrm{H}, \mathrm{dd})\right.$, $5.34(1 \mathrm{H}, \mathrm{ddd})$, and $6.11(1 \mathrm{H}, \mathrm{dd})$, respectively], and one amido proton was shifted at $\delta_{\mathrm{H}} 5.43 ; 1 \mathrm{H}$, s (Table 1$)$.

The ${ }^{13} \mathrm{C}$-NMR data of 1 (Table 2) showed 30 carbon signals including four methyls $\left(\delta_{\mathrm{C}} 13.8,19.5,24.3\right.$, and 21.0), three carbonyls including two ketones and one ester which were shifted at $\delta_{\mathrm{C}} 173.8,210.4$, and 169.9 , respectively, and two couples of identical aromatic carbon signals $\mathrm{C}-2^{\prime} / \mathrm{C} 6^{\prime}$ and $\mathrm{C}-3^{\prime} / \mathrm{C}-5^{\prime}$ which were shifted at $\delta_{C} 129.3$ and 129.1 , respectively. Using DEPT, it can be inferred that signals at $\delta_{C} 173.8,147.7,53.7,210.4,77.8$, 169.9 , and 137.4 are quarternary carbon atoms.

The heteronuclear multiple bond correlation (HMBC) correlation also showed a correlation from $\mathrm{H}-10 \mathrm{a}\left(\delta_{\mathrm{H}} 2.67\right)$ to C-3 $\left(\delta_{\mathrm{C}} 53.4\right), \mathrm{C}-1$ ' $\left(\delta_{\mathrm{C}} 137.4\right), \mathrm{C}-2$ '/C-6' $\left(\delta_{\mathrm{C}} 129.3\right)$, from $\mathrm{H}-10 \mathrm{~b}$ $\left(\delta_{\mathrm{H}} 2.82\right)$ to $\mathrm{C} 3\left(\delta_{\mathrm{C}} 53.4\right)$, from $\mathrm{H}-21\left(\delta_{\mathrm{H}} 5.63\right)$ to $\mathrm{C} 4\left(\delta_{\mathrm{C}} 50.2\right)$, $\mathrm{C} 20\left(\delta_{\mathrm{C}} 132.5\right)$, and $\mathrm{C} 13\left(\delta_{\mathrm{C}} 127.8\right)$, and from $\mathrm{H}-8(2.85)$ to C7 $\left(\delta_{C} 70.0\right)$ and $C-1\left(\delta_{C} 173.8\right)$, which supported the 3-benzylsubtituted isoindolone skeleton and the HMBC correlations from an exocylic proton $\mathrm{H}-12 \mathrm{a} / \mathrm{H} 12 \mathrm{~b}$ to quarternary carbons $\mathrm{C}-5$ and $\mathrm{C} 7$, and from methyl proton $\mathrm{H}-11$ to quarternary carbons $\mathrm{C}-5$, and C-6 which indicated that the structure of compound $\mathbf{1}$ was analogous to cytochalasins (Fujii et al., 2000; Feng et al., 2002; Lin et al., 2009; Liu et al., 2006; 2008; Xue et al., 2012; Zhang et al., 2008). Other studies have reported that most cytochalasin skeletons share the same stereochemistry (viz., cis-configurations atC-8/C-9 and C-4/C-9 ring junctions), and it has been proposed that the macrocyclic skeleton is stable and relatively rigid despite the large ring size and different functionalities (Buchanan et al., 1996; Feng et al., 2002; Liu et al., 2006; 2008).

The ${ }^{1} \mathrm{H}$ - and ${ }^{13} \mathrm{C}-\mathrm{NMR}$ data of isolated compound was identic with cytochalasin D as shown in Tables 1 and 2 with a slightly different in measured of chemical shift of proton of $\mathrm{NH}$ moiety for isolated $[5.43(\mathrm{~s}, 1 \mathrm{H})]$ and reported by Luo et al. (2007) $(5.28$, brs, 1H). However, the chemical shift of NH moiety of cytochalasin D reported by Xu et al. (2001) was appeared in more downfield area $(5.53$, brs, $1 \mathrm{H})$, with no hydroxy signals $(7-$ $\mathrm{OH}$ and $18-\mathrm{OH})$. The difference of this chemical shift is probably caused by availability of small amount of $\mathrm{H}_{2} \mathrm{O}$ molecules in the NMR sample that affect to the chemical shift of proton on $\mathrm{NH}$ moiety. Based on the above data, it was concluded that the isolated compound from Xylaria sp. DAP-KRI-5 is cytochalasin $\mathrm{D}$ and indicated the molecular formula of $\mathrm{C}_{30} \mathrm{H}_{37} \mathrm{NO}_{6}$ that agree with molecular formula of cytochalasin D published on http://dnp. chemnetbase.com (Buckingham et al., 2010).

Antibacterial assays for compound 1 compared with commercial antibiotics (streptomycin, vancomycin, and chloramphenicol) appeared in Table 3. Chemical structure of cytochalasin D is shown in Figure 1.

\section{DISCUSSION}

In this study, cytochalasin D, a fungal metabolite was successfully isolated from Xylaria sp. DAP KRI-5. Xylaria sp. DAP KRI-5 is an endophytic fungus that was isolated from the
Table 1. ${ }^{13} \mathrm{C}$-NMR data of compound $\mathbf{1}$ and Cytochalasin D in $\mathrm{CDCl}_{3}(125 \mathrm{MHz})$.

\begin{tabular}{|c|c|c|c|}
\hline \multirow{2}{*}{ C no. } & 1 & Luo et al., 2007 & Xu et al., 2001 \\
\hline & $\delta \mathrm{C}$ & $\delta \mathrm{C}$ & $\delta \mathrm{C}$ \\
\hline 1 & 173.8 & 173.8 & 173.6 \\
\hline 3 & 53.4 & 53.3 & 53.2 \\
\hline 4 & 50.2 & 49.8 & 50.0 \\
\hline 5 & 32.8 & 32.6 & 32.6 \\
\hline 6 & 147.7 & 147.5 & 147.5 \\
\hline 7 & 70.0 & 69.8 & 69.8 \\
\hline 8 & 47.1 & 46.9 & 47.0 \\
\hline 9 & 53.7 & 53.5 & 53.5 \\
\hline 10 & 45.5 & 45.2 & 45.3 \\
\hline 11 & 13.8 & 13.6 & 13.6 \\
\hline 12 & 114.7 & 114.4 & 114.5 \\
\hline 13 & 127.8 & 127.5 & 127.6 \\
\hline 14 & 130.8 & 130.6 & 130.6 \\
\hline 15 & 37.9 & 37.7 & 37.7 \\
\hline 16 & 42.5 & 42.3 & 42.3 \\
\hline 17 & 210.4 & 210.2 & 210.2 \\
\hline 18 & 77.8 & 77.6 & 77.7 \\
\hline 19 & 134.3 & 134.0 & 134.1 \\
\hline 20 & 132.5 & 132.3 & 132.3 \\
\hline 21 & 77.2 & 77.0 & 77.3 \\
\hline 22 & 19.5 & 19.3 & 19.4 \\
\hline 23 & 24.3 & 24.1 & 24.2 \\
\hline 24 & 169.9 & 169.6 & 169.7 \\
\hline 25 & 21.0 & 20.8 & 20.8 \\
\hline $1^{\prime}$ & 137.4 & 137.2 & 137.2 \\
\hline $2^{\prime}, 6^{\prime}$ & 129.3 & 129.1 & 129.1 \\
\hline $3^{\prime}, 5^{\prime}$ & 129.1 & 128.8 & 128.9 \\
\hline $4^{\prime}$ & 127.3 & 127.0 & 127.1 \\
\hline
\end{tabular}

A. papuana Becc plant. This compound was characterized by spectrometry (1D- and 2D-NMR, and HRMS) and was confirmed as cytochalasin $\mathrm{D}$.

Cytochalasin D was first isolated from Metarrhizium manisopliae by Aldridge et al. (1967) and it was also known as zigosporin A because it was produced by the fungus Zygosporium mansonii (Hayakawa et al., 1968), and was also isolated from Engleromyces goetzii (Jikai et al., 2002). However, there are no data citing the bioproductive capacity of cytochalasin D by Z. mansonii, M. manisopliae, or E. goetzii.

In other studies, cytochalasin D was also produced by Xylaria sp. SCSIO 156 and Daldinia concentrica (Chen et al., 2011; Luo et al., 2007). The bioproductive capacity of cytochalasin D was reported from Xylaria sp. SCSIO 156, and Xylaria sp. BT05: 0.00126 and $0.00085 \mathrm{~g} / 1$ of its liquid culture medium, respectively (Chen et al., 2011; De Felício et al., 2015). It has been produced by $X$. arbuscula with a bioproductive capacity around $0.52733 \mathrm{~g} / \mathrm{l}$ (Amarala et al., 2014). In this present study, Xylaria sp. DAP KRI-5 produced cytochalasin 
Table 2. ${ }^{1} \mathrm{H}-\mathrm{NMR}$ data of compound 1 and cytochalasin $\mathrm{D}$ in $\mathrm{CDCl}_{3}(500 \mathrm{MHz})$.

\begin{tabular}{|c|c|c|c|}
\hline \multirow{2}{*}{ C. no. } & 1 & Luo et al., 2007 & Xu et al., 2001 \\
\hline & $\delta \mathbf{H}$ & $\delta \mathbf{H}$ & $\delta \mathbf{H}$ \\
\hline 1 & - & - & - \\
\hline 3 & $3.23(\mathrm{~m}, 1 \mathrm{H})$ & $3.23(\mathrm{~m}, 1 \mathrm{H})$ & $3.22(\mathrm{~m}, 1 \mathrm{H} J=4.5,4.0)$ \\
\hline 4 & $2.14(\mathrm{dd}, 1 \mathrm{H}, J=4.4,3.9)$ & $2.14(\mathrm{dd}, 1 \mathrm{H}, J=4.4,3.8)$ & $2.14(\mathrm{t}, 1 \mathrm{H}, J=5.0)$ \\
\hline 5 & $2.72(\mathrm{~m}, 1 \mathrm{H})$ & $2.72(\mathrm{~m}, 1 \mathrm{H})$ & $2.83(\mathrm{~m}, 1 \mathrm{H}, J=10.5,5.0,2.0)$ \\
\hline 6 & - & - & - \\
\hline 7 & $3.81(\mathrm{~d}, 1 \mathrm{H}, J=10.4)$ & $3.80(\mathrm{~d}, 1 \mathrm{H}, J=10.6)$ & $3.80(1 \mathrm{H}, \mathrm{d}, J=10.5)$ \\
\hline 8 & $2.85(\mathrm{t}, 1 \mathrm{H}, J=10.4,9.1)$ & $2.84(\mathrm{dd}, 1 \mathrm{H}, J=10.1,9.8)$ & $2.84(\mathrm{~m}, 1 \mathrm{H}, J=5.0,2.0)$ \\
\hline 9 & - & - & - \\
\hline \multirow{2}{*}{10} & $2.67(\mathrm{dd}, 1 \mathrm{H}, J=13.3,9.1)$ & $2.68(\mathrm{dd}, 1 \mathrm{H}, J=13.4,9.2)$ & $2.65(\mathrm{dd}, 1 \mathrm{H}, J=13.5,9.5)$ \\
\hline & $2.82(\mathrm{dd}, 1 \mathrm{H}, J=13.6,5.2)$ & $2.81(\mathrm{dd}, 1 \mathrm{H}, J=13.4,5.3)$ & $2.83(\mathrm{~m}, 1 \mathrm{H}, J=13.5,10.0,2.5)$ \\
\hline 11 & $0.96\left(\mathrm{~d}, 3 \mathrm{H}, J=6.5, \mathrm{CH}_{3}\right)$ & $0.91\left(\mathrm{~d}, 3 \mathrm{H}, J=6.7, \mathrm{CH}_{3}\right)$ & $0.95\left(\mathrm{~d}, 3 \mathrm{H}, 7.0, \mathrm{CH}_{3}\right)$ \\
\hline \multirow{2}{*}{12} & $5.09(\mathrm{~s}, 1 \mathrm{H})$ & 5.07 (brs, $1 \mathrm{H})$ & $5.09(\mathrm{~s}, 1 \mathrm{H})$ \\
\hline & $5.29(\mathrm{~s}, 1 \mathrm{H})$ & $5.28(\mathrm{brs}, 1 \mathrm{H})$ & $5.29(\mathrm{~s}, 1 \mathrm{H})$ \\
\hline 13 & $5.14(\mathrm{dd}, 1 \mathrm{H}, J=15.6,2.6)$ & $5.13(\mathrm{dd}, 1 \mathrm{H}, J=15.7,2.3)$ & $5.35(\mathrm{~m}, 1 \mathrm{H}, J=15.5,10.0,5.0)$ \\
\hline 14 & $5.69(\mathrm{dd}, 1 \mathrm{H}, J=15,6,9.8)$ & $5.67(\mathrm{dd}, 1 \mathrm{H}, J=15.4,9.8)$ & $5.65(\mathrm{dd}, 1 \mathrm{H}, J=15.5,10.0)$ \\
\hline \multirow{2}{*}{15} & $2.02(\mathrm{dd}, 1 \mathrm{H}, J=12.9,5.2)$ & $2.01(\mathrm{dd}, 1 \mathrm{H}, J=12.7,4.8)$ & $2.02(\mathrm{dd}, 1 \mathrm{H}, J=13.5,11.0)$ \\
\hline & $2.51(\mathrm{dd}, 1 \mathrm{H}, J=12.95,11.05)$ & $2.50(\mathrm{ddd}, 1 \mathrm{H}, J=12.7,11.1,11.1)$ & $2.51(\mathrm{dd}, 1 \mathrm{H}, J=13.5,11.0)$ \\
\hline 16 & $2.74(\mathrm{~m}, 1 \mathrm{H})$ & 2. $72(\mathrm{~m}, 1 \mathrm{H})$ & $2.73(\mathrm{~m}, 1 \mathrm{H}, J=11.0,4.5)$ \\
\hline 17 & - & - & - \\
\hline 18 & - & - & - \\
\hline 19 & $5.34(\mathrm{ddd}, 1 \mathrm{H}, J=15.5,10.5,5.2)$ & $5.32(\mathrm{ddd}, 1 \mathrm{H}, J=15.7,10.7,5.2)$ & $5.35(\mathrm{~m}, 1 \mathrm{H}, J=15.5,10.0,5.0)$ \\
\hline 20 & $6.11(\mathrm{dd}, 1 \mathrm{H}, J=15.6,2.6)$ & $6.10(\mathrm{dd}, 1 \mathrm{H}, J=15.7,2.6)$ & $6.11(\mathrm{dd}, 1 \mathrm{H}, J=16.0,2.5)$ \\
\hline 21 & $5.63(\mathrm{t}, 1 \mathrm{H}, J=2.6)$ & $5.61(\mathrm{dd}, 1 \mathrm{H}, J=2.6,2.3)$ & $5.63(\mathrm{t}, 1 \mathrm{H}, J=2.5)$ \\
\hline 22 & $1.19\left(\mathrm{~d}, 3 \mathrm{H}, J=7.2, \mathrm{CH}_{3}\right)$ & $1.19\left(\mathrm{~d}, 3 \mathrm{H}, J=6.8, \mathrm{CH}_{3}\right)$ & $1.20\left(\mathrm{~d}, 3 \mathrm{H}, J=7.0, \mathrm{CH}_{3}\right)$ \\
\hline 23 & $1.51\left(\mathrm{~s}, 3 \mathrm{H}, \mathrm{CH}_{3}\right)$ & $1.50\left(\mathrm{~s}, 3 \mathrm{H}, \mathrm{CH}_{3}\right)$ & $1.51\left(\mathrm{~s}, 3 \mathrm{H}, \mathrm{CH}_{3}\right)$ \\
\hline 24 & - & - & - \\
\hline 25 & $2.26\left(\mathrm{~s}, 3 \mathrm{H}, \mathrm{CH}_{3}\right)$ & $2.25\left(\mathrm{~s}, 3 \mathrm{H}, \mathrm{CH}_{3}\right)$ & $2.26\left(\mathrm{~s}, 3 \mathrm{H}, \mathrm{CH}_{3}\right)$ \\
\hline 1 ' & - & - & - \\
\hline $2^{\prime}, 6^{\prime}$ & $7.12(2 \mathrm{H}, \mathrm{d}, J=7.1)$ & $7.13(\mathrm{~d}, 2 \mathrm{H}, J=7.2)$ & $7.25(\mathrm{~m}, 2 \mathrm{H}, J=15.0,7.0,1.5)$ \\
\hline $3^{\prime}, 5^{\prime}$ & $7.31(\mathrm{t}, 2 \mathrm{H}, J=7.1)$ & $7.31(\mathrm{t}, 2 \mathrm{H}, J=7.3)$ & $7.25(\mathrm{~m}, 2 \mathrm{H}, J=15.0,7.0,1.5)$ \\
\hline 4 ' & $7.25(\mathrm{t}, 1 \mathrm{H}, J=7.8)$ & $7.23(\mathrm{t}, 1 \mathrm{H}, J=7.3)$ & $7.25(\mathrm{~m}, 1 \mathrm{H}, J=15.0,7.0,1.5)$ \\
\hline NH & $5.43(\mathrm{~s}, 1 \mathrm{H})$ & $5.28(\mathrm{brs}, 1 \mathrm{H})$ & $5.53($ brs, $1 \mathrm{H})$ \\
\hline $7-\mathrm{OH}$ & $1.91(\mathrm{~s}, 1 \mathrm{H})$ & $2.03(\mathrm{~s}, 1 \mathrm{H})$ & nd \\
\hline $18-\mathrm{OH}$ & $4.65(\mathrm{~s}, 1 \mathrm{H})$ & 4.64 (brs, 1H) & nd \\
\hline
\end{tabular}

Table 3. Antibacterial activity of cytochalasin $\mathrm{D}$ and some commercial antibiotics.

\begin{tabular}{lcccc}
\hline \multirow{2}{*}{ Tested bacteria } & \multicolumn{3}{c}{ MIC value (ug/ml) } \\
\cline { 2 - 3 } & \multicolumn{3}{c}{ Commercial antibiotics } & \multirow{2}{*}{ Cytochalasin D } \\
\cline { 2 - 4 } & Chloramphenicol & Streptomycin & Vancomycin & \\
\hline Gram-positive bacteria & 4 & 0.5 & $>32$ \\
S. aureus-InaCC* B4 & 2 & 2 & 0.5 & $>32$ \\
B. subtilis-InaCC B1 & 16 & & $>32$ \\
Gram-negative bacteria & 8 & 32 & $>32$ & $>32$ \\
E. coli-InaCC B5 & 32 & $>32$ & & \\
P. aeruginosa-InaCC B3 & & &
\end{tabular}




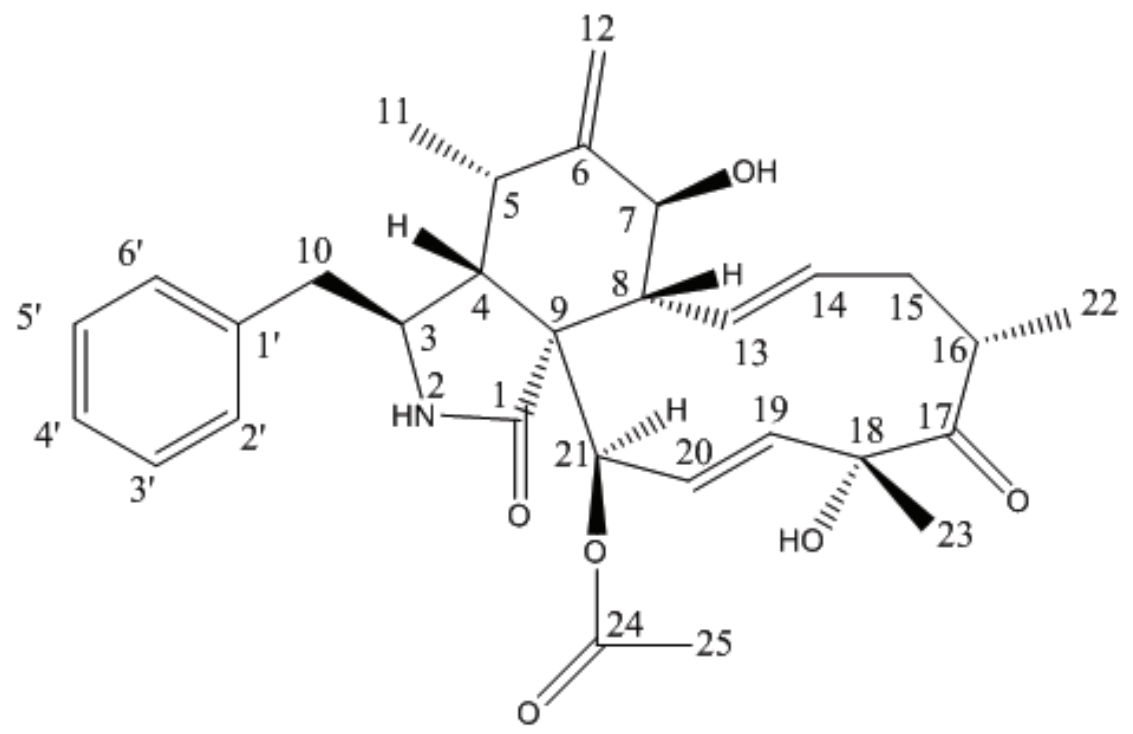

Figure 1. The structure of cytochalasin D.

Table 4. Bioproduction capacity of cytochalasin D isolated from some fungi.

\begin{tabular}{|c|c|c|c|c|}
\hline No & Source & Medium & Bioproduction Capacity (g/l) & Literatures \\
\hline 1. & Zygosporium mansonii & $3 \%$ glucose, $2 \%$ peptone, and $0.5 \%$ sodium, chloride in sterilized water $(\mathrm{pH} 6.8)$ & nd & Hayakawa et al., 1968 \\
\hline 2. & Metarrhizium anisopliae & nd & nd & Aldridge et al., 1967 \\
\hline 3. & Daldinia concentrica & nd & nd & Luo et al., 2007 \\
\hline 4. & Engleromyces goetzii & nd & nd & Jikai et al., 2002 \\
\hline 5. & Xylaria sp. SCSIO 156 & $\begin{array}{l}2 \% \text { mannitol, } 2 \% \text { malt extract, } 1 \% \text { glucose, } 1 \% \text { sodium glutamate, } 0.05 \% \mathrm{KH}_{2} \mathrm{PO}_{4}, 0.03 \% \\
\mathrm{MgSO}_{4} \cdot 7 \mathrm{H}_{2} \mathrm{O}, 0.1 \% \text { corn meal, } 0.3 \% \text { yeast extract, and } 3 \% \text { sea salt in distilled water }(\mathrm{pH} 6.5)\end{array}$ & 0.00126 & Chen et al., 2011 \\
\hline 6. & Xylaria sp. ВT05 & Rice in seawater $(1,000 \mathrm{~g} / \mathrm{l})$ & 0.00085 & De Felício et al., 2015 \\
\hline 7. & Xylaria arbuscula & Wheat in distilled water $(1,333 \mathrm{~g} / \mathrm{l})$ & 0.52733 & Amaral et al., 2014 \\
\hline 8. & Xylaria sp. DAP KRI-5 & PDB in sterilized water $(24 \mathrm{~g} / \mathrm{l})$ & 0.05763 & The present study \\
\hline
\end{tabular}

nd $=$ no data.

D with a bioproductive capacity of $0.05763 \mathrm{~g} / 1$ (Table 4). The bioproductive capacity of Xylaria sp. DAP KRI-5 is less than that of $X$. arbuscula because the $X$. arbuscula (wheat: $1,333 \mathrm{~g} / 1$ ) culture medium contains more free amino acids and proteins than the Xylaria sp. DAP KRI-5 (PDB: 24g/l) culture medium. The level of free amino acid and proteins in the culture medium are essential factors of the production of cytochalasin D (Amarala et al., 2014).

In this study, cytochalasin D was tested for antibacterial agent against Gram-positive bacteria (Table 3) with a MIC value of $>32 \mu \mathrm{g} / \mathrm{ml}$. Cytochalasin D was less active than the commercial antibiotics chloramphenicol, streptomycin, and vancomycin. Meanwhile, the MIC value of cytochalasin D was similar to vancomycin against Gram-negative bacteria (>32 $\mu \mathrm{g} / \mathrm{ml})$. In other studies, cytochalasin D has been reported to have activity as an antitumor, antineoplastic, antiviral, antianaphylactic, antifungal, and disruptor of actin polymerization agents (Betina et al., 1972; Cohen et al., 1999; Oppenheimer et al., 1995; Shin et al., 1997; Trendowski, 2015; Wang et al., 2003). This compound is effective as a disruptor of microfilament formation so it could act as a chemotherapeutic agent (Trendowski, 2015).

\section{CONCLUSION}

The endophytic fungus Xylaria sp. DAP-KRI-5 that is associated with the $A$. papuana Becc. plant can produce cytochalasin D with a bioproductive capacity of $0.05763 \mathrm{~g} / 1$ in PDB medium. Cytochalasin D was less potent as an antibacterial agent against Gram-positive and negative bacteria than several commercial antibiotics.

\section{ACKNOWLEDGMENTS}

The study was supported by the DIPA(Internal Institution Fund) Research Center for Biology, Indonesian Institute of Sciences (LIPI). The authors are very grateful to the Indonesian Ministry of Research and Technology which supported the first author's graduate scholarship. We thank Dr. Praptiwi who helped to collect A. papuana plant, Muhammad Ilyas who identified Xylaria sp. DAP KRI-5, and Andi Saptaji Kamal for his technical assistance in this research. We also thank Dr. Lina de Montigny who proofread this manuscript.

\section{CONFLICT OF INTEREST}

There are no conflicts of interest. 


\section{REFERENCES}

Agusta A, Ohashi K, Shibuya H. Bisanthraquinone metabolites produced by the endophytic fungus Diaporthe sp. Chem Pharm Bull, 2006; 54(4):579-82.

Aldridge DC, Armstrong JJ, Speake RN, Turner WB. The cytochalasins, a new class of biologically active mould metabolites. Chem Commun (London), 1967;1:26-7.

Amarala Lda S, Rodrigues-Filho E, Santos CA, de Abreu LM, Pfenning LH. An HPLC evaluation of cytochalasin D biosynthesis by Xylaria arbuscula cultivated in different media. Nat Prod Commun, 2014; 9(9):1279-82.

Betina V, Micekova D, Nemec P. Antimicrobial properties of cytochalasins and their alteration of fungal morphology. J Gen Microbiol, 1972; 71:343-9.

Buchanan S, Hashimoto T, Takaoka S, Kan Y, Asakawa Y. A 10-phenyl-[11]-cytochalasin from a species of Daldinia. Phytochemistry, 1996; 42(1):173-6.

Buckingham J, Baggaley KH, Roberts AD, Szabo LF (eds.). Dictionary of alkaloids. 2nd edition, CRC Press, Taylor \& Francis Group, Boca Raton, FL, p 2041, 2010.

Chen Z, Huang H, Chen Y, Wang Z, Ma J, Wang B, Zhang W, Zhang $\mathrm{C}$, Ju J. New cytochalasins from the marine-derived fungus Xylaria sp. SCSIO 156. Helv Chim Acta, 2011; 94:1671-6.

Cohen E, Ophir I, Shaul YB. Induced differentiation in HT29, a human colon adenocarcinoma cell line. J Cell Sci, 1999; 112:2657-66.

De Felício R, Pavao GB, de Oliveira ALL, Erbert C, Conti R, Pupo MT, Furtado NAJC, Ferreira EG, Costa-Lotufo LV, Young MCM, Yokoya NS, Debonsi HM. Antibacterial, antifungal and cytotoxic activities exhibited by endophytic fungi from the Brazilian marine red alga Bostrychia tenella (Ceramiales). Rev Bras Farmacogn, 2015; 25:641-50.

Fathoni A, Ilyas M, Praptiwi, Cahyana AH, Agusta, A. Screening and isolation of antibacterial active metabolite from the culture of endophytic Fungi from Albertisia papuana Becc. Berita Biologi, 2013; 12(3):307-14.

Feng Y, Blunt JW, Cole ALJ, Munro MHG. Three novel cytochalasins X, Y, and Z from Pseudeurotium zonatum. J Nat Prod, 2002; 65(9):1274-7.

Frattarelli DAC, Reed MD, Giacoia GP, Aranda JV. Antifungals in systemic neonatal candidiasis. Drugs, 2004; 64:949-68.

Fujii Y, Tani H, Ichinoe M, Nakajima H. Zygosporin D and two new cytochalasins produced by the fungus Metarrhizium anisopliae. J Nat Prod, 2000; 63(1):132-5.

Hayakawa S, Matsushima T, Kimura T, Minato H, Katagiri K. Zygosporin A. A new antibiotic from Zygosporium mansonii. J Antibiotics, 1968; 21(8):523-4.

Jikai L, Jianwen T, Zejun D, Zhihui D, Xianghua W, Peigui L. Neoengleromycin, a novel compound from Engleromyces goetzii. Helv Chim Acta, 2002; 85:1439-42.

Lin ZJ, Zhang GJ, Zhu TJ, Liu R, Wei HJ, Gu QQ. Bioactive cytochalasins from Aspergillus flavipes, an endophytic fungus associated with the Mangrove plant Acanthus ilicifolius. Helv Chim Acta, 2009; 92(8):1538-44.

Liu R, Gu Q, Zhu W, Cui C, Fan G, Fang Y, Zhu T, Liu H. 10-Phenyl-[12]-cytochalasins Z7, Z8, and Z9 from the marine-derived fungus Spicaria elegans. J Nat Prod, 2006; 69(6):871-5.
Liu R, Lin Z, Zhu T, Fang Y, Gu Q, Zhu W. Novel open-chain cytochalasins from the marine-derived fungus Spicaria elegans. J Nat Prod, 2008; 71(7):1127-32.

Luo DQ, Tang HL, Yang XL, Wang F, Liu JK. Fungicidal activity of L696,474 and cytochalasin D from the ascomycete Daldinia concentrica against plant pathogenic fungi. Acta Phytophylacica Sin, 2007; 34(2):113-22.

Oppenheimer DI, Volkman LE. Proteolysis of p6.9 induced by cytochalasin D in Autographa californica M nuclear polyhedrosis virusinfected cells. Virology, 1995; 207:1-11.

Petrini O. Fungal endophytes of tree leaves. In: Fokkema NJ, Heuvel JVD (eds.). Microbial ecology of the leaves. Cambridge University Press, Cambridge, UK, pp 185-7, 1991.

Praptiwi T, Jamal Y, Fathoni A, Nurkanto A, Agusta A. Antibacterial activity of Bisanthraquinone(+)-1,1'-bislunatin. Microbiol Indones, 2013; 7(4):159-66.

Scott LJ, Curran MP, Figgitt DP. Rosuvastatin: a review of its use in the management of dyslipidemia. Am J Cardiovasc Drugs, 2004; $4: 117-38$

Shin HY, Lee EH, Shin TY, Kim HM. Effect of cytochalasin D on systemic and local anaphylaxis in a murine model. Pharmacol Res, 1997; $36: 141-6$.

Stierle A, Strobel G, Stierli D. Taxol and taxane production by Taxomyces andreanae, an endophytic fungus of pacific yew (Taxus brevifolia). Science, 1993; 260(5105):214-6.

Trendowski M. Using cytochalasins to improve current chemotherapeutic approaches. Anti-cancer Agents Med Chem, 2015; 15:327-35.

Wang JF, Huang YJ, Xu QY, Zheng ZH, Zhao YF, Su WJ. X-ray crystal structure of cytochalasin D produced by Tubercularia sp., a novel endophytic fungus of Taxusmairei. J Chem Crystallogr, 2003; 33:51-6.

$\mathrm{Xu}$ H, Fang WS, Chen XG, He WY, Cheng KD. Cytochalasin D from Hypocrella Bambusae. J Asian Nat Prod Res, 2001; 3(2):151-5.

Xue M, Zhang Q, Gao JM, Li H, Tian JM, Pescitelli G. Chaetoglobosin $\mathrm{Vb}$ from endophytic Chaetomium globosum: absolute configuration of chaetoglobosins. Chirality, 2012; 24(8):668-74.

Zhang HW, Song YC, Tan RX. Biology and chemistry of endophytes. Nat Prod Rep, 2006; 23:753-77.

Zhang Y, Tian R, Liu S, Chen X, Liu X, Che Y. Alachalasins A-G, new cytochalasins from the fungus Stachybotrys charatum. Bioorg Med Chem, 2008; 16(5):2627-34

How to cite this article:

Fathoni A, Agusta A. Bioproduction of cytochalasin D by endophytic fungus Xylaria sp. DAP KRI-5. J Appl Pharm Sci, 2019; 9(03):105-110. 